\title{
Collective Violence and Public Health: The Experience of the Oromo People in Ethiopia
}

\author{
Begna F. Dugassa \\ Toronto Public Health, Toronto, Canada \\ Email: b.dugassa@utoronto.ca
}

How to cite this paper: Dugassa, B. F. (2017). Collective Violence and Public Health: The Experience of the Oromo People in Ethiopia. Sociology Mind, 7, 102-127. https://doi.org/10.4236/sm.2017.73008

Received: April 3, 2017

Accepted: July 4, 2017

Published: July 7, 2017

Copyright $\odot 2017$ by author and Scientific Research Publishing Inc. This work is licensed under the Creative Commons Attribution International License (CC BY 4.0).

http://creativecommons.org/licenses/by/4.0/

\begin{abstract}
Background: For over a hundred and fifty years, consecutive Ethiopian regimes have perpetuated collective violence against the Oromo people. During those years, the Oromo people have been denied their collective rights i.e. the right to decide on their social, economic, political, cultural and environmental affairs. Objectives: In this paper, I explore the ways collective violence and the denial of the collective right of the Oromo people has hindered the development of better public health conditions. Methods: In this paper, using the WHO definition of health as "a state of complete physical, mental and social well-being and not merely the absence of disease or infirmity" and collective violence as "the instrumental use of violence by people who identify themselves as members of a group, whether this group is transitory or has a more permanent identity, against another group or set of individuals, in order to achieve political, economic or social objectives" as the framework of thinking explore the relationships between collective violence and the under-development of public health conditions. Finding: The core functions of public health are assessing social conditions that contribute to health and diseases, developing healthy policies, widening people's choices in life and assuring their implementation. The optimum development of public health can be achieved if societies continuously strive to prevent diseases through the promotion of healthy social policies. Collective violence and the violation of collective rights hinder the social, economic, political, cultural and environmental capacity of the Oromo people. This impairs the development of public health. Conclusion: Collective violence and the violation of collective rights are profoundly contrary to the objective of a public health agenda. The prevention of collective violence and promotion of collective rights should be seen as an essential condition necessary to the development of the social, economic, political, cultural and environmental capacity of the Oromo people and the development of public health conditions.
\end{abstract}

\section{Keywords}

Collective Violence, Violation of Collective Rights, Public Health, Colonial Social Policy, Public Health, Ethiopia, Oromia 


\section{Introduction}

Ethiopia is a multi-ethno/national empire and Oromos are the single largest ethnic group (Holcomb \& Ibsa, 1990). In Oromia, instability, poverty, famine and epidemic diseases are prevalent. None of them are caused by natural calamities; they are the manifestations of the violations of collective rights. Consecutive Ethiopian regimes have deliberately worked to incapacitate the social, economic, political and cultural capacity of the Oromo people and made them vulnerable to poverty, famine and diseases. The UN founding document-the UDHR-is an instrument set up to protect individuals against actions that meddle with human dignity. The principles of human rights are designed to respect, protect and fulfill the needs of people as well as promote peace (see UDHR, 1948). Although Ethiopia signed many of the UN charters, most of them have not been implemented. Widespread killings, imprisonment, instability, poverty and famine are the manifestations of the absence of regard for human rights (Dugassa, 2008).

Perhaps we can best understand the issue that this article attempts to address if we start by reflecting on the accounts of Oromo people under different Ethiopian regimes. Under consecutive Ethiopian kings (Tewedros, Yohanis and Menelik) in the bloody and attritional wars from 1860 to 1918, Oromia was incorporated into the current Ethiopian Empire (Holcomb \& Ibsa, 1990). In the process of colonization, the Oromo population was reduced by two-thirds (de Salviac, 1901/2005; Bulatovic, 2000). The major causes were killings, starvation, slave trade and epidemic diseases i.e. rinderpest virus ${ }^{1}$, cholera and the Spanish flu. Starvation resulted from the war, the rinderpest virus (cattle plague) and widespread looting by the Abyssinian army. The cattle plague, cholera and the Spanish flu were not indigenous to the Horn of Africa. These epidemics emerged in the region because of the military movements of European empire builders such as the British, French and Italians (Dugassa, 2009). In Oromia's case, it was the Abyssinian army that was directly responsible for the spread of these deadly infections.

After colonization, the Oromo people were denied the right to decide on their social, economic, political, cultural and environmental affairs (Holcomb \& Ibsa, 1990). In their own land, the Oromo people became serfs and were forced to give up a quarter to three quarters of their harvests to Abyssinians (Jalata, 2005; Lata, 2000). Vital Oromo institutions were either banned or incapacitated. For example, the Oromo institutions "Gada and Siqee" were either fully banned or incapacitated. The Oromo religious institution Waqeefaata was banned and Orthodox Christianity was imposed upon the Oromo people. The Oromo people were denied the right to decide on their affairs; they were forced to wait on the good will of the Ethiopian government. This hindered the development of public health and community resiliency (Dugassa, 2008).

Consistent with the view of the European colonizers, the Ethiopian government framed its agenda as a "civilizing" mission ( ${ }^{\circ} \not \dot{\phi} \zeta$ ') (Dugassa, 2014a). After they pacified the Oromos, the Ethiopian government described their mission as

${ }^{1}$ The rinderpest killed over $95 \%$ of Oromo cattle and several kinds of wild animals. 
a unifying force-implying a reclaiming of their ancestral territory. The desire of the Ethiopian government to control, exploit and assimilate the Oromo people impoverished and incapacitated them. The Ethiopian government policy makers knowingly compromised the needs of the Oromo people. This was manifested in the higher illiteracy level, poverty, persistent famine and widespread, easily preventable infectious diseases (Dugassa, 2009) and nutritional deficiencies (Dugassa, 2013). Denying people the right to decide on their social, economic, political, political and environmental affairs creates unhealthy social conditions and increases their vulnerability. From the Oromo perspective, colonialism equates with poverty, increased vulnerability to poverty and diseases.

During the Dergue regime (1974 to 1991), young Oromo men were massively conscripted into the Ethiopian military and many of them died on the war front. Moreover, the Oromo people were forced to finance the war. Millions of young Oromo men who were conscripted died in the war front and millions were wounded and returned back to their villages with no compensation. Most of those who were wounded could not effectively work at physically demanding farm work. The widespread conscription further increased poverty level and increased the risk factors for HIV/AIDS and other diseases (Dugassa, 2005).

\section{Research Objectives}

Public health researchers and policy makers usually ask critical questions and make efforts to answer them. They usually ask questions such as: where do diseases or social ills begin? Trying to answer these questions, they start systematically collecting data and defining the problem and answering the "who", "what", "where", "when" and "how". This leads to a second set of questions: what are the risk factors and protective factors that relate to the problems? As they answer the second set of questions, they start to ask a third set that helps them envision strategies to reduce the risks and widen the protective factors. This leads to the third set of questions-where researchers and policy makers adopt risk reduction and prevention strategies.

To highlight the importance of teamwork and individuals' work, an African proverb states "if you want to go fast, go alone; if you want to go farther, you need go with a team". Consistent with the proverb, historical evidence shows that societies can more effectively build decent public health if they assert their collective rights. Equally, creativity and the aspirations of individuals can be suppressed and needs can be undermined if collective rights overwhelmingly dominate individual rights. If societies allow individual rights to dominate collective rights, then some individuals might behave unethically. This necessitates balancing those rights. The major objective of this paper is to trace the colonial knowledge i.e. (ideas and ideologies) that have promoted the colonial social order and provided theoretical reasons for the collective violence in Oromia. The second objective is to provide the theoretical reasoning that preventing collective violence, protecting collective and individuals' rights are essential in promoting public health. 


\section{Collective Violence and Social Theories}

As I explore the ways the European empire builders provided a theoretical reasoning for Abyssinia and constructed a social force that perpetuated collective violence, colonized Oromia and created people without autonomy, I reveal the relationships between theory and practice. The word "theory" comes from a Greek word "theoria" that means seeing and inward looking or envisioning. In other words, a theory is a body of knowledge or a postulation about what ought to be. Social theories are about describing, explaining and addressing social relations. To theorize is to use our mind's eye and systematically articulate guiding principles (Krieger, 2001).

Public health researchers usually ask where the social and biological causes of diseases and the health differences among social groups originated. If we trace the social causes of diseases back to the deepest roots, we are half-way to finding solutions. What pathways lead from root causes to disease and create the differences in health status that are observed at the population level? In light of the answers to these questions, we can learn where and how we should intervene to prevent disease and reduce health inequities. Indeed, tracing the root causes is a step forward in addressing them. Colonial policies are driven with profit and control in mind and are not expected to create healthy social conditions for the colonized people or help them solve their problems.

In public health, tracing the social and biological causations of diseases are important. To trace the social causes of health problems in Oromia, we need to first examine the Euro-Abyssinian relations. Second, we need to closely look at the social theories that European empire builders provided to Abyssinia. Understanding these issues help trace the origins of the colonial agenda and allow us to understand the social problems that followed. When the European colonizers defined the land of indigenous people as "terra nullius" - empty land - they were manufacturing theoretical reasons. The term "terra nullius" implies that the ways indigenous peoples used their natural resources and governed themselves are different from the Europeans and therefore "invalid". As Foucault explained the relationships between knowledge, power and health (Foucault, 1980), power sets discursive practices that characterize the work of social systems. This means conceptualizing the indigenous people's land as "terra nullius", legalized colonizing and compromising the needs of the indigenous people.

The Abyssinian and European relation conceived in the twelfth century at the time when the conflicts between the Muslim expansion and Christian Europe reached its highest level. In the hope of stopping the Muslim expansion, a myth about Preston John emerged among the Christian clergy. The myth suggested that he was a committed Christian king and controlled a big empire and was ready to free the Holy city from Muslim hands. In 1498, when the Portuguese explorers led by Vasco da Gama arrived in India, one of their objectives was to find the empire of Prester John. However, when they could not establish the Christian empire in Asia they started to look in Africa. As the explorers found that Abyssinia was a Christian state, they wittingly declared they had found the empire of Prester John 
(Dugassa, 2008). Until recently Abyssinia was known as the land of Prester John.

When the Portuguese explorers established contact with Abyssinia, they taught the Abyssinian clergy the myths about the size of Prester John's territory as facts. The myth "immensely exaggerated the size of Abyssinian territory" and suggests that it stretched from south of Egypt to South Africa (Ramos, 2003). To quote Harley (1989) "power comes from the map"; based on these theories, the Abyssinian elites started to dream of empire building. Indeed, based on the Prester John map that over exaggerated their territory, when the Abyssinians invaded Oromia, they said they were just reclaiming their former territories and ancestral land. The Oromo people, who had been in that region from time immemorial, were presented as outsiders and migrants. Later sections, I closely look at the ways the myth that the Portuguese gave to Abyssinia became a theoretical reason to envisage a bigger Abyssinian empire and explore the experiences of the Oromo people under different Abyssinian regimes. I will show the ways the colonial agenda perpetuated harm, introduced/exacerbated poverty, homelessness and diseases.

\subsection{Understanding Collective Rights}

The International Covenant on Economic, Social and Cultural Rights (ICESCR) (see, ICESCR, 1966) and the International Covenant on Civil and Political Rights (ICCPR) (see, ICCPR, 1966) Article 1, "clearly states that collective rights include the political, and economic, social and cultural development." This means collective rights include the right to speak one's native language and educate one's children in their language; the right to the cultural preservation of the group. This includes the rights of peoples to their ancestral lands and resources held collectively, and the right to pass land and resources down through the generations. Furthermore, collective rights include environmental rights i.e. the right to clean air, water, and land. The right to restitution for lands stolen from the collective ownership and the right to development. Most importantly, collective rights recognize the right to national self-determination, including independence or autonomous self-government.

What is the importance of collective rights to a population's health? To answer this question we need to closely look at the concept of public health. The WHO (1998) defined Public Health as "the art and science of preventing disease, prolonging life and promoting health through the organized efforts of society". According to the CDC, (CDC, 2013) public health is "the science of protecting and improving the health of families and communities through the promotion of healthy lifestyles, research for disease and injury prevention and detection and control of infectious diseases". The WHO and CDC definitions make clear that the efforts societies make to improve public health conditions are intended to achieve a public good and go beyond an individual's efforts. Improvements in public health conditions require collective efforts. This makes collective rights prerequisites to the development of public health. Indeed, the primary responsibility for promoting healthy social conditions rests with government. The poli- 
cies of Ethiopian consecutive regimes notably did not, and do not, take into consideration the needs of the Oromo people; instead, the policies knowingly and unintentionally exposed them to known and unknown risks.

When the issue of collective rights is raised, many Ethiopians worry about its impacts. Conservative Ethiopians believe that if the collective rights of people are guaranteed, the territorial integrity of the empire will be shattered. This view does not have a valid moral and legal justification. Research and practice shows that the ideas and ideologies that can bring different groups of people together and help them build unity are respect for human rights, human dignity and human security. Ethiopians need to struggle to guarantee their rights and the rights of others. All need to make efforts to assure that all individuals and groups live in dignity and have control of conditions that put them at risk. If they work together, they can achieve their collective desires. Therefore, the best tool to promote unity among people and peace is by promoting human rights.

There are many people who promote people's unity. The current form of union is not necessarily good for all ethno/national groups. Ethiopian unity should be tailor-made by all ethno/national groups, and it should be based on the idea and principle of the power balance. It should not be imposed from the outside or by one group; it should grow from the inside and encompass all ethnic groups. Indeed, it is not Ethiopian territorial integrity or people's unity that is at stake; it is the Ethiopian identity. Many believe that the Ethiopian identity has been imposed upon them. They argue that the Ethiopian identity neither represents the Abyssinians or non-Abyssinians. However, they resist any imposed form of unity, identity and history especially one with the colonial subtext.

\subsection{Collective Rights and Identity}

Identity politics is an integral part of collective rights. Indeed, political activism is all about the efforts societies make to define and defend who they are and who they are inspired to be. In the case of Oromos, identity politics is essentially the efforts they make to define and defend Oromo aspirations i.e. name their needs and find solutions to their problems. This means identity politics is a struggle societies make to develop contingency plans (i.e. free from poverty, famine and preventable diseases) as well as to define and defend who they are. It is an essential condition for the very survival of a society. However, if identity politics are misguided, instead of fostering political freedom they can foster oppression. Racism and anti-racism are part of identity politics. Racism promotes hierarchical identity, it promotes un-freedom and unhealthy politics and it lacks moral justification. However, political freedom makes the decision-making process transparent, fair and inclusive.

Since the Ethiopian state was formed, Ethiopianess has been widely debated. For example, from 1960 to 1970, in the circle of the Ethiopian student movement, there was an understanding that Ethiopianess meant belonging to the Orthodox Church and speaking Amharic or Tigrigna languages. There are two major discourses surrounding Ethiopian identity. The first discourse presents 
the idea that Ethiopia has three thousand years of history-the name was mentioned in the Holy Bible (Dugassa, 2006b). These theorists promote that Ethiopianess is a privilege; it represents the old civilization. They want to maintain such an identity. The second discourse presents the idea that the term Ethiopia ${ }^{2}$ came from two Greek words meaning the land of burned face people. It has nothing to do with the people in Africa because it is an imposed by outsiders (Dugassa, 2006b). This group argues that maintaining such an identity is legitimizing colonial ideological impositions.

Policy makers need to recognize the importance of these two powerful discourses and need to work to harmonize these differences. For example, in the 1980s when many Oromo political prisoners faced extreme torture, they were accused of being enemies of Ethiopia. The torturers clearly expected to forcefully impose the Ethiopian identity upon them. The desire to self-determination is natural to the human character and even under such extreme conditions many of them resisted impositions. Indeed, under such extreme conditions some of the Oromo political prisoners have said "even if you grind my bones and flesh, you cannot mold my bones and flesh and produce an Ethiopian".

Policy makers need to play a middle ground role in understanding the differences between two identity discourses. The middle ground should be found in human rights principles. The imposition of ideas, ideologies and identity are contrary to human rights principles. We need to encourage the idea of diversity in history, identity and unity in human dignity, decency and security. The resistance to the Ethiopian identity cannot be separated from the inhuman treatment that the Oromo people have experienced under consecutive Ethiopian regimes. Promoting human rights and human dignity is acknowledging the pain and the indignity that others have faced or are facing and it is the effective way of promoting unity, and even collective identity.

\section{The Fate of the Oromo People under Different Abyssinian Regimes}

\subsection{Tewodros II (1848-58)}

Abyssinian history makes clear that Tewodros II's birth name was Kassa Hailuwas not born in the royal family and he started his career as an outlaw ( After he built a sizable force and instituted bloody wars he claimed power. In the Abyssinian circle, he was recognized as the king who theoretically ended decentralization and sought to reestablish a cohesive Abyssinian state. He was inaugurated in 1855 on the prophecy that he would restore the Ethiopian Empire to greatness, to its former splendor, destroy the pagans and Islam and raise the Cross above the Crescent. Indeed, he got the name Tewodros to fulfill the resto-

\footnotetext{
${ }^{2}$ When I was an elementary school student sitting around the fireplace, I asked my father, mother and grandmother to name their country. None of them mentioned Ethiopia. When I told them their country is Ethiopia, they say "it is pastor Tsega's country"-an Orthodox Church pastor. When I saw the pastor, I asked him to name his country, he said "I am Gojame"-a province in Amhara region. It is evident that neither the Oromos nor the Abyssinians identified themselves as Ethiopian.
} 
ration prophesy (Mekuria, 1985/1992; Bulcha, 2005). According to Bulcha $(2005)^{3}$, Tewodros was one of the most violent of all Abyssinian monarchs'. He personally hacked thousands of Oromo people to death. The method of killing include mutilating hands and throwing them into ditches (Mekuria, 1985/1992). He used Christianity as an ideology to bring him close to the European empire builders. He wrote a letter to Queen Victoria requesting that skilled workers come to Abyssinia to teach his citizens how to produce firearms. In writing, he made his objectives clear that he aimed at the restoration of the ancient kingdom of Ethiopia. Tewodros reactivated the old myth about the size of the Abyssinian territory and used that as an ideology to perpetuate ethnic cleansing against the Oromo people.

\subsection{Yohanis IV (1879-1889)}

Yohanis IV was a Tigray ultra-nationalist and radical Christian king. He banned Tigray nationals, targeting their fellow Tigray people for slavery (Pankhurst, 2005). He ordered every Tigray family to tattoo a cross on their children's forehead and two half-moons on each side of their eyelids. The cross implied that they were Christians and the two half-moons represented that they were friends of Islam. By introducing such a measure, he protected the Tigray nationals from slave traders (Dabaas, 1988). This measure provided a theoretical reason why non-Christians and Muslims should be subjected to slavery. Ultimately this made the people who practiced indigenous religion, like the Oromos, the targets of slavery.

Yohanis IV legalized the eviction of non-Christians from Oromo territories captured in the war. For example, in the Boru Meda decree, Yohanis and Menelik passed a law that states all non-Christians either leave the land under their rule and flee or convert to Christianity. The decree gave a four-year grace period for Muslims and two years for indigenous believers (Mekuria, 1982/1989). Many Oromos who had refused conversion were evicted from Wallo and forced to flee to Sudan; others went south and settled in different parts of Oromia (Yilma, 2006/2013).

In addition, Yohanis IV effectively perpetrated genocide against the Oromo people in Raya and Azebo. He ordered his army to kill all the old and young, men and women, and even burn the natural forests in those regions. The king made it clear that those who showed mercy to the Oromo people and their natural forests would face extreme brutality. In doing that, Yohanis destroyed the natural resources of Rayya and Azebo and exterminated the people (Reta \& Adisu, 2005/2012).

Moreover, Yohanis IV's reckless leadership caused a public health catastrophe. Although Yohanis commanded a big army, they were not salaried. Usually the army looted whatever they wanted from the people they conquered. In 1887,

${ }^{3}$ The Oromo Oral story suggests that Tewodros II was killed by the army of Queen Workitu of Wallo, which contradicts the discourse Abyssinians present that he committed suicide refusing to surrender to the British forces. 
the Abyssinian army invaded the Italian military camp in Massawa and looted cattle infected with rinderpest virus. Imprudently, the army took these cattle to the highlands of Eritrea and kept them with other cattle, which led to the spread of the infection. The infection spread like wild fire and massively killed domestic cattle and wild animals and caused famine. The rinderpest infection brought devastation to cattle, people and the environment in Ethiopia and all sub-Saharan African countries. Abyssinian literature documented this as Ph4. \$3 "mean days" or "evil days". Furthermore, Yohanis established diplomatic contacts with the European empire builders and through them he had his own personal doctor and acquired a smallpox vaccination. He allowed the vaccination to be given only to the nobility thereby introducing a discriminatory health policy (Pankhurst, 2005).

\subsection{Menelik II (1889-1913)}

Although Menelik's predecessors dreamed of restoring the mythical former territorial borders, none of them achieved it. Menelik partly achieved the mythical goal and created a modern empire. In Abyssinian circles, he is seen as the one who had made great efforts to restore the ancient Ethiopian Kingdom to its glory by expanding his kingdom to the south, east and west. The expansion of the frontier did not happen by peaceful means. Menelik consolidated his power with the guns and military advisors he acquired from the British, Italian, French and Russians ${ }^{4}$. He began a long-term war in which millions of people died. Menelik paid for the military hardware and slaves he captured in the war. Indeed, at one point Menelik II personally owned 70,000 slaves (Bulcha, 2002).

The Oromo people charged Menelik II with perpetuating genocide against them. His army perpetuated mass killings and mutilated hands and breasts in different parts of Oromia. The Oromo people also charged the king with using rinderpest virus as a biological weapon to wipe out their cattle. The unsalaried Menelik army also committed widespread lootings. Menelik massively settled starving and armed Abyssinians in different parts of Oromia. When armed Abyssinians travelled to settlements, they took whatever cattle they had. This made the rinderpest virus quickly spread over all Oromia regions. In settling armed Abyssinians, Menelik authorized them to claim Oromo lands, to demand the Oromo people work for them, and provide them with food and shelter. The Oromo people were more dependent on cattle than the Abyssinians and the impacts of rinderpest were more severe in Oromia. The mass lootings and the settlements further aggravated food insecurity in Oromia and this contributed to the deaths of millions of Oromo people. Because he provided them food looted from Oromia, free labor and land, Menelik was widely referred to among Abyssinians as " mos charge Menelik is his policy of forceful religious conversion. The Abyssi-

${ }^{4}$ Menilik believed that Russians are the true partners. Both are Orthodox Christians and profess the same faith; and Russia has no colonial agenda in Africa and would not compete in colonial expansion. 
nian racist view is deeply settled in their episteme; his predecessors forcefully imposed Orthodox Christianity, and its morality, upon the Oromo people.

\subsection{King Iyasu and Queen Zewudity (1913-1930)}

From 1913 to 1930, Ethiopian politics can be explained as the period of reform and counter-reform. King Iyasu inherited the power from his grandfather when he was 14 years old. He was born of the Oromo father and for this reason Abyssinian elites disapproved of him (Yilma, 2006/2013). The young king tried to make the Oromo and Amhara relations equitable. He recruited different ethnic groups to his army and built churches and mosques. This intent to reform was seen as deserting Christianity and he was removed from the throne in 1916. Subsequently, Zewditu was inaugurated as a Queen and Ras Tafari (later known as Haile Selassie) as a regent. Zewditu spent most of the time consolidating her power (Yilma, 2006/2013).

\subsection{The King Haile Selassie Regime (1930-1974)}

During King Haile Selassie's regime, and before, in Oromia the great majority of the people were Waqefaata-the followers of the indigenous religion. However, before the mid-1970s, every Waqefaata was forced to go through a mandatory Orthodox Church Baptism. What were the impacts of such religious impositions? The Oromo worldview is one of accumulated knowledge and it provided them directions in life, maintained their social order and gave them hope in despair. The Oromo worldview is essential to define who they are as people and whom they want to be. Delegitimizing the Oromo worldview uprooted them from their culture and forced them to abandon their accumulated wisdom, making them vulnerable to assimilation. The accumulated wisdom had sustained the Oromo people for centuries and delegitimizing it took away their sustenance tools and exposed them to known and unknown risks.

Notably until the mid-1970s, seventy percent of the Oromo farmlands were owned by the Abyssinian elites and their institutions (Lata, 2000). At that time, Oromo farmers gave a quarter to three quarters of their harvests to Abyssinian elites and institutions (Orthodox church and monarch), paid taxes i.e. state, education, health with no services provided in return. Violations of collective rights of Oromo people, such as being dispossessed of land and the imposition of one language, religion and the dismantling of their institutions, weakened them.

One of the major policies of Ethiopian regimes was to assimilate the Oromo people into the Abyssinian culture. For this reason, the Oromo people were forced to accept Orthodox Christianity and adhere to their religious holidays. In the Ethiopian Orthodox Christianity, out of 30 days in a month, there are fortyfour holidays. In some cases, there is more than one holiday in a day. On those holidays, Oromo farmers were not allowed to work on their farms (Dugassa, 2004). Using the Oromo language in court, schools and for religious teachings was legally banned (Bulcha, 1995). For example, in one land ownership dispute court case an Oromo man was charged for referring to the Supreme Court judge 
as ( 放 = anchi) "you”, a term used in Amharic in reference to women,-instead

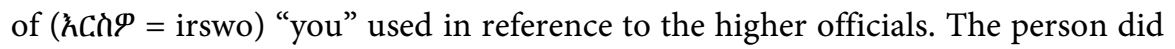

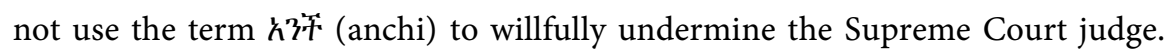
The reason was that he did not fully understand the Amharic language (Dugassa, 2014b).

\subsection{The Dergie Regime (1974-1991)}

The military government developed three major policies that have had devastating impacts on the Oromo people. As previously stated, one was the policy of conscripting millions of young Oromo men to the military. The conscripted young Oromo men were angry at the Ethiopian authorities and they did not want to fight the war. To appease these angry men, the Ethiopian military allowed them to leave military camps and spend a day or two in the nearby cities and towns. For those angry young men, a vacation is an opportunity to be high on alcohol and spend time with commercial sex workers (Dugassa, 2003). This was a depression management strategy. This exposed them to HIV/AIDS. What became clear later is that the conscripts were not informed about HIV/AIDS and its prevention methods. In 1991, when the war abruptly ended, the conscripted and the standing Ethiopian army were disbanded and sent back to their villages, towns and cities. Most of them were infected with the HIV/AIDS and spread the virus throughout the country (Dugassa, 2009).

The conscripted Oromo men were angry at the Ethiopian government authorities and they resisted fighting the war. When the situation permitted, they surrendered to the Tigray People Liberation Front $\left(\mathrm{TPLF}^{5}\right)$ and the Eritrean People Liberation Front (EPLF) forces. The EPLF forces handed the Prisoners of War (POW) to the TPLF. In the TPLF military camps, the fate of Oromo men conscripted to the military turned from bad to worse. Initially, the TPLF used these POWs as human shields to protect them from the Ethiopian government army attacks. However, after the TPLF fully liberated the Tigray region, they realized that forming an independent state of Tigray was not viable. Hence, they decided to take the whole of Ethiopia. When the TPLF decided to change their objectives, they realized that the Oromo Liberation Front (OLF) was popular among the Oromo people. To tackle that, the TPLF decided to write a political program, handed it to the Oromo POWs and declared the formation of a political party known as the Oromo People's Democratic Organization (OPDO). Not long after the formation of OPDO was revealed, the TPLF media declared the formation of a political alliance known as the Ethiopian People Revolutionary Front (EPRDF), which theoretically constitutes the TPLF, the Amhara National Democratic Movement (ANDM) and OPDO. Afterwards, the TPLF used the OPDO to kill Oromo people and rule Oromia (Dugassa, 2012).

The second ill-intended program was villagization. In the villagization program, Oromo farmers were forced to abandon their former settlements (dispersed settlements) and make bigger villages. The Oromo farmers were forced to

\footnotetext{
${ }^{5}$ The Southern Ethiopian People's Democratic Movement (SEPDM) formed by the TPLF in 1992.
} 
dismantle their houses and build new ones in overcrowded areas. The Ethiopian government said that the objective of this program was to promulgate socialist farming. The Oromo people saw the program differently. The Ethiopian government started the program in eastern and southern Oromia. The initial objective of the program was to control the Oromo national movement. As the government already temporarily controlled the national movement in eastern and southern parts of Oromia, they adapted their program for other regions. The newly built villages were overcrowded, poorly designed and sanitary conditions were not good. Infection started in a family, was quickly transmitted and affected the whole village. Cattle infection started in one herd easily spread to others, and as a result Oromo farmers lost most of their herds. There were cases when a fire started in one place wiped out the whole village (Dugassa, 2009).

The third dangerous program was the resettlement program. In this program, the Ethiopian government brought Abyssinians to settle in Oromia (Pankhurst, 1992). When they settled them, the government evicted Oromos from their farmlands to provide space for the settlers. The Oromo farmers were forced to work for the settlers, build their houses and feed them until they could fully fend for themselves. The eviction of Oromo farmers from their lands forcing them to work for settlers, and feeding them, further aggravated poverty levels. The settlers were armed and the Ethiopian government used them to control the social and political activities of the Oromo people (Clay \& Holcomb, 1986). The settlers introduced several infectious diseases that were not common to Oromia. The resettlement program also caused deforestation because in some cases the settlers cut down forests to expand their farmlands and in other cases the Oromos, who had lost their farms to the settlers, destroyed the forest to expand their farmlands (Dugassa, 2009). The program caused many people to flee from the country as refugees (Clay \& Holcomb, 1986). It was an environmental and public health disaster.

\subsection{TPLF Regime (1991 to Present)}

The TPLF represents the Tigray people that constitute six percent of the people in Ethiopia. Though the TPLF represents only a minority group, it oppresses and dominates the Oromo people. As previously stated, the formation of the OPDO was meant to counterbalance the Oromo national movement objectives, which are to guarantee the collective rights of the Oromo people. When the TPLF formed the OPDO, it was intended to deny the Oromo people leadership and representation in policy making. The TPLF constitutionally assured the rights of nations and nationalities and theoretically adopted the federation of different ethnic groups. Though regional states are named after ethno-national groups, all of them are ruled by the TPLF. The TPLF adopted a divide and rule strategy and created tension between different ethnic groups.

As the Oromo people are the single largest ethnic group, they are most targeted by the TPLF. In the settlement of the Oromo people, Oromia should have borders with all regional states. However, in order to incapacitate the Oromo 
people the TPLF applied a divide and rule strategy and made part of the Oromo region-Raya and Qobbo-part of the Tigray Region (Reta \& Adisu, 2005/2012). Parts of the Oromo lands were incorporated into the Amhara, Benishangul, Southern Nations, Nationalities, and Peoples' Region (SNNP) region, Harari and Afar regions. In addition, the TPLF created three federal cities in Oromia. In areas where the Oromo lands are incorporated into different regions, the Oromo people are denied the use of their language in schools and at work. The TPLF also adopted a policy to massively evict the Oromo people from their lands and either settle non-Oromos in the area or lease the farm lands to local and international corporations. Human rights activists and Oromo scholars charge that the TPLF government has been guilty of ethnic cleansing (Dugassa, 2009).

According to the Human Rights League of the Horn of Africa (HRLHA) and the Oromo Support Group (OSG), since 1992 over two million Oromos have been evicted from their homes. About 300,000 people were evicted in the Finfinee (Addis Ababa) area alone. During the same period, about half a million Oromos were forced to flee as refugees, over a million people were imprisoned and over 10,000 civilians and about half a million activists killed. In 2014, the Ethiopian government revealed a plan designed to expand the city of Finfinee, a plan that would have evicted over 10 - 15 million people. The plan triggered the Oromo protests in November 2015; since then, the protest has engulfed Oromia and other regions. From November 2015 to the present, over 3000 peaceful Oromo protesters have been killed, over one hundred thousand imprisoned and thousands have been forced to flee as refugees. These refugees include men and women who have been risking their lives on the Mediterranean to reach Europe.

To contain the growing Oromo protest, the Ethiopian government has declared a state of emergency and effectively transferred power from civilian rule to military rule by creating several military command posts. Although the peaceful protesters are simply demanding respect for human rights, the state of emergency decree has further criminalized the exercising of basic human rights. For example, the state of emergency criminalized 1) listening to radios and watching TV channels that are critical of Ethiopian government policies; 2) posting anything on social media and organizing meetings 3) protesting or organizing protests; 4) displaying protest gestures, 5) visiting factories during curfews; 6) restricting diplomats from traveling more than $40 \mathrm{~km}$ from the capital and g) having guns (BBC, 2016).

The state of emergency further legalized human rights violations. The Ethiopian army is stationed in all cities, towns and small villages. The state of emergency decree authorized the army to arrest and even kill anyone whom they suspect of being involved in antigovernment protests, with little or no evidence. The decree gave the army the power to go into private homes and take TVs and satellite dishes. The army went beyond what the decree authorized and looted money, jewelry, cellphones and other valuable items. They also raped women.

In Oromia, the impacts of the state emergency have been devastating. First, hundreds of thousands of Oromos have been imprisoned and are spending their 
productive time in jail. Fearing the widespread killings and imprisonments, thousands are running away from their homes. This further aggravates the existing poverty level and exposes communities to known and unknown diseases. Second, legalizing the confiscation of private property such as TVs and satellite dishes violates the right of people to information and entertainment. Third, confiscating private property is ethically wrong; it further widens the gap between the rulers and the ruled, creating fertile ground for instability. Fourth, the Ethiopian army are known sexual adventurists and many of them are HIV positive. Military command posts are stationed in many areas including hard-to-reach areas of the country, and they are most likely to spread HIV/AIDS. From the Oromo perspective, overcoming poverty and disease is an act of struggle for justice.

Markedly Ethiopia is a multinational/ethnic state/empire and the Oromo people are the single largest national group. The Amhara, the Somali, the Tigray, the Sidama and the Gurage people represent the second, third, fourth, fifth and the sixth most popular groups. Currently the fourth largest ethnic group-the Tigray people who constitute six percent of the Ethiopian population-politically dominate the others. The official language of the Ethiopian federal government is Amharic. When it comes to Federal government employment, 18\% are Oromos, $50 \%$ are Amhara, $8 \%$ are Tigray and $4 \%$ are Gurage. This means employment in the federal government disproportionally favors the Amhara, Tigray and Gurage (Midega, 2014).

In addition, in the major Oromia cities i.e. Finfinee (Addis Ababa), Dire Dawa and Harar, the Oromo people are denied the use of their language in schools, courts and in workplaces. Because of the evictions and long standing discriminatory Ethiopian government language policies, in Finfinee the Oromo language is only the second most important language. However, in Dire Dawa and Harari, the Oromo language is the most spoken language. Such a discriminatory language policy has hindered the Oromo people from knowing of the existence of HIV/AIDS and how to prevent it (Dugassa, 2006a). The Ethiopian Language policy is part of the Abyssinian cultural superiority theory and it is a clear violation of the collective rights of Oromo people (Bulcha, 1994).

The Ethiopian language policy is just one of the many examples of collective rights violations. The violation of such a right compromises the right of Oromo people to enjoy the highest attainable health. The UN Vienna Declaration and Programme of Action of 1993 reconfirmed the importance of individual and collective rights and clearly stated that: "All human rights are universal, indivisible and interdependent and interrelated." This document made clear that human rights are universal, indivisible and interdependent and interrelated; states cannot pick and choose regarding which human rights it has to protect (UN Vienna Declaration, 1993).

In 1999/2000, Ethiopia and Eritrea fought a bloody war on a border dispute. In the war, over 150,000 people have died. The population of Ethiopia is bigger than Eretria and has a much bigger army. To counterbalance the bigger Ethio- 
pian army, the Eritrean government fortified their border with mines. To break the fortified line, the Ethiopian government used Oromo men as cannon fodder and minesweepers. The Guardian News reporter stationed in Eritrea during the war David Hirst ${ }^{6}$ (Hirst, 1999) described it thus:

If the conduct of war is a measure of a government's fitness and ability to rule, then Tsorona is a terrible indictment of the TPLF. It was Oromo peasants it selected as human minesweepers, and Tigrayan officers who shot them from the rear.

The TPLF's political philosophy is guided by racist theories i.e. the culturally superior theory. For them, cultural practices that are different from Abyssinian ones are seen as "inferior". When the Oromo people demanded their language be one of the Federal Government official languages and opposed evictions from their lands, the TPLF characterized them as "wicked". For example, the Ethiopian Minister of Information, Mr. Getachew Reda, described the Oromo protesters as: Mr. Reda described the Oromo protesters as demons and Satan and their demands as the work of witchcraft, he provided theoretical reasons for the TPLF army making the killings morally acceptable and even a duty. The October 2, 2016 massacre on the Indigenous Oromo Religious Thanksgiving festival-Irrecha, in which over 675 people were killed, is not separate from the TPLF cultural racist views and the statements made by Mr. Reda that provide theoretical reasons for collective violence against the Oromo people.

Human rights activists need to take Mr. Reda's hateful remarks about the Oromo protesters seriously. For example, hate language and incitements broadcast by media are well known genocidal tools. Indeed, from the Armenian genocide, the genocide of the Jews to the genocide of the Tutsis, perpetrators have used similar terms in the media in reference to the victims such as "filth," "cancer," "parasites," "microbes" and cockroaches. The literature of genocide prevention also suggests that medical metaphors that dehumanize people are the warning signs of genocide (Richter, (2008). When Mr. Reda described the Oromo protesters as demons, Satan, and characterized their demands as the work of witchcraft, he was dehumanizing them.

\section{Framework of Thinking}

A theoretical framework is a "blueprint" for the research; it serves as the guiding idea on which the research questions are framed, the data is collected and interpreted. In its constitution, the WHO defined health as "a state of complete physical, mental and social well-being and not merely the absence of disease or infirmity". It stated that the highest attainable quality of health is one of the fundamental rights of every human being (WHO, 2006). The constitution made it clear that health is not something that we simply wish to have, but it is something we fight for. Also, the WHO defined collective violence as "the instrumen-

${ }^{6}$ Human waves fall as war aims unfold https://www.theguardian.com/world/1999/may/18/ethiopia. 
tal use of violence by people who identify themselves as members of a groupwhether this group is transitory or has a more permanent identity-against another group or set of individuals, in order to achieve political, economic or social objectives (See, WHO, 2002). In this paper, these WHO statements are used as a framework of thinking (WHO, 2006).

\section{Human Rights and Public Health}

Human rights principles obligate states to respect, protect and fulfill the needs of people. From the 1860s to the present, consecutive Ethiopian regimes not only failed to respect, protect and fulfill, but rather failed to uphold the principle of human rights and deliberately perpetuate collective violence and created unhealthy social conditions.

The principles of human rights, the promotion of human dignity, security and public health i.e. preventing disease, prolonging life and promoting health, are all intertwined. Regard for human rights is instrumental in early risk identification, reducing the underlying risk factors and strengthening disaster preparedness (Da Costa \& Pospieszna, 2015). Human rights and public health work synergistically. The sum of the two (human rights and public health) is greater than the two working separately. As human rights principles are intended to respect, protect the dignity and freedom of people; guaranteeing such rights creates healthy social conditions. The UN Vienna Human Rights Charter of 1993 asserts this when it states, "all human rights are universal, indivisible and interdependent and interrelated" (UN Vienna Charter, 1993).

The Ethiopia government presents the social problem in Oromia in biomedical terms i.e. poverty; diseases and illiteracy. In reality, the social problems that the Oromo people face are not separate from their social status. Their poverty levels and public health problems are the manifestations of their lack of decision-making powers. The duties and responsibilities of leadership are to envision future directions, strengthen collective identity, build trust and cooperation and guide society to attain its desired goals. Violations of such rights deny society the right to envision better directions and having a purpose in life. Denial of the right to develop their own leadership is an integral component of the denial of the right to existence of the entire community i.e. Genocide (Dugassa, 2012; Jalata, 2005).

Hoping to provide a framework of thinking to address the social problems in Ethiopia, I have been studying political movements in the region. The aspirations of people in the empire encompass both collective and individual rights. However, some of the political parties have framed their program by focusing on individual rights and undermining collective rights. Other put more focus on collective rights. The party in power-the TPLF-theoretically promotes both collective and individual rights but in practice acts contrary to both principles and plays games as it sees fit. The TPLF government officially promotes collective rights i.e. Federalism; however, it made the Tigray nationals dominate the others. For example, when the TPLF formed the Oromo People's Democratic 
Organization (OPDO) from the POWs, it intended to use them to deny the Oromo people their own leadership. Furthermore, the TPLF provides political and financial initiatives for one ethnic group to fight against another and thereby created conflicts.

In the Western world in the last hundred years, life expectancy has increased by over 30 years. Improvements in life expectancy have been achieved through 1) monitoring the health status of the community; 2) investigating health problems and hazards; 3) informing people about health issues; 4) mobilizing the community to identify health problems; 5) developing policies and plans that support community health; 6) enforcing laws that protect health and ensure safety; 7) linking people to personal health; 8) assuring a competent public healthcare system; 9) evaluating the effectiveness of health services; 10) researching innovative solutions to health problems (CDC, 2014). All these public health measures are influenced by political decision makers. This makes prevention of diseases and the promotion of health profoundly political matters (Bambra et al., 2005).

Health is political because the social determinants of health i.e. the social, economic, political, and cultural status of people, are all determined by political actions or inactions. The major objectives of public health policy are to create a supportive social environment and enable people to lead healthier lives. Public health policy-making is a well-planned decision-making process. In actions and inactions, political power is usually exercised. It is for this reason that violations of human rights have direct serious health consequences or increase vulnerability to ill health in Oromia. Conversely, promoting human rights is inextricably linked to promoting good public health (WHO, 2002).

The history of human rights is the struggle for justice. Although all human struggles are focused on achieving dignity and security, they separately provide unique approaches to these issues. These differences are based on how to achieve human dignity and security. The United Nations (UN) was formed after the Second World War, and was designed to protect human rights and promote peace. Due to the historical reality of the time, most of the founders of the UN were Euro-American countries. The Universal Declaration of Human Rights (UDHR), which is referred to in human rights literature as the first generation of human rights, is dominated by Protestant ethics. Protestant ethics promote the need for individuals to take responsibility and guarantee his/her own security. Hence, the first generation of human rights predominantly focused on promoting individual rights.

In the 1960s, when several countries were liberated from colonial rule, they started to promote human rights based on ethics founded in cultures other than ones based on Protestant ethics. Hence, the second generation of human rights focuses more on collective rights. For example, the International Covenant on Economic, Social and Cultural Rights (ICESCR) and the International Covenant on Civil and Political Rights (ICCPR) Article 1, states "all peoples have the right of self-determination. By virtue of that right they freely determine their political 
status and freely pursue their economic, social and cultural development." The African Charter on Human and Peoples Rights also emphasizes collective rights. The Ethiopian government is signatory to the ICESCR and the ICCPR and the African Charter on Human and Peoples Rights (African Charter).

To bring peace, stability and better public health conditions to Oromia and surrounding regions a paradigm shift is needed. In October 2016, I was invited to speak at a conference organized by Amnesty International on human rights violations in Oromia and Ethiopia. Half of the audience were Ethiopians. Most of the questions the audience asked me during and after my presentation made me think more deeply. They asked me whether or not I was an Ethiopian. They wanted to know whether or not I support Ethiopian history written in homogeny or from diverse perspectives. I answered that my rights have been violated in Ethiopia and it is for this reason I migrated to Canada. I said, "I prefer to identify myself as an Oromo-Canadian". On the question of Ethiopian history, I said "history is a discourse. If history is a discourse there is no reason to worry if the history of a country or an empire is written from different perspectives". I disputed that denial of differences is a denial of justice. Instead, I suggested that there was a need to focus on promoting human rights, human dignity, decency and human security, because they are essential, and universal. A respect for human rights i.e. (individuals' and collective rights) are essential conditions to guarantee human security, dignity and foster unity.

The underlying conditions to health and wellbeing are the social, economic, political and cultural status of people. Let me provide some evidence why collective violence is dangerous to human dignity, security and public health. In many Western countries, indigenous peoples' life expectancy is up to 20 years lower than their non-indigenous counterparts (McCaskill et al., 2011). Indigenous cultures, knowledge, and languages are threatened with extinction. They are increasingly losing their identity and lands, and often caught in no man's land. The challenges that the indigenous face result from colonial social policies. Ethiopia needs to learn from the wrongs done in the Western world. This necessitates promoting theories and practices that prevent collective violence and guarantee collective and individual rights.

In 1996, in Ethiopia the number of Oromo, Afar and Somali women who had heard of the existence of HIV/AIDS lagged behind that of women in the Amhara and Tigray regions. Not only that, among those women who have heard of the existence of the disease, many were reluctant to believe the information (Dugassa, 2006a). The reasoning for that is the discriminatory Ethiopian language policy. Here is what I have said in my work:

In 1996 a friend introduced me by telephone to his friend from Finfine. A year later, I learned that this person had died. To express my condolence I called his wife. In our conversation she told me that she was also sick. I asked her what was happening, hoping to know whether or not she was aware of the AIDS/HIV epidemic. I asked her whether or not she watched television and listened to the radio. She said, "I do not understand Amharic. 
The Afaan Oromo program soon after it has started you will find it is finished." During the television show in Afaan Oromo she said, "they talk about their propaganda, who is going to listen to their lies? In our coffee gathering I heard about a baleful shadow that is going around." I asked her what the baleful shadow was. She answered, "it is the shadow of evil that is flying around. If that shadow passed on your clothes that you put to dry in the sun you will catch the disease. The person who is caught by the disease would die a year later and there is no medication for the disease 'Waaqni haan akkas namaa habaasu'. (Let God forbid such tragedy)". She passed away a year later (Dugassa, 2006a: p. 80).

Clearly Ethiopian language policy violated the right of the Oromo people to know about the conditions that put them at risk.

\section{Evictions and Public Health}

Evictions of Oromo people from their land have been going on since the 1860s. To understand the impacts on the lifespan of Oromo people we need to closely look at the recent experiences. From 1992 to 2017, over two million Oromos have been evicted from their homes and among them 300,000 were from the Finfinee (Addis Ababa) area (Legesse, 2014). Most Oromos who were evicted are farmers. The major skills of these farmers are cultivating crops and rearing domestic animals. Most of them live in a lean economy and have few mobile resources and have large families. In the past, when they were evicted, they moved far away from their homes and communities, leaving behind their immobile properties. In many cases they were evicted from malaria free zones and settled in malaria prone zones. In recent cases, most evicted farmers were moved to Finfinee, because it is the fastest growing city. As the Oromo farmers moved to the city, the social, economic, cultural, political institutions that usually protected them from harm would not help, because they were banned. In the next section, I look at the pathways in which eviction exposes Oromo farmers to poverty, malnutrition and diseases.

First, land is a major resource for Oromo farmers and their economic wellbeing is dependent on it. They work on their farms and provide basic necessities to their family members. Seasonally they produce different types of fruits, vegetables and grain products as well as animal products. Some of the products they sell in the market. On their farms they also have basic shelter. Although most Oromo farmers live in a lean economy, they have the basic necessities. However, when they are evicted from their lands, they are left in absolute poverty and homelessness.

Second, in the countryside housing and sanitary conditions are not perfect. However, given that their settlements were dispersed, the natural environment takes care of human and animal wastes. When they are evicted and forced to move to cities they are conditioned to live in overcrowded settings, where human waste overwhelms the capacity of the natural environment to clean. This conditioned Oromo farmers to live in poor sanitary conditions. This makes 
them prone to easily preventable chronic and acute diseases.

Third, in the countryside farmers consume freshly harvested fruits and vegetables which are nutritionally rich. When they move to a city, the nutritional quality of the foods they can afford is lower than freshly harvested ones. They cannot afford to have fridges and preserve their fruits and vegetables. This exposes them to micro-macro-nutrient deficiencies.

Fourth, in villages, Oromo farmers were surrounded by family and community members who are culturally and biologically bonded and deeply care for each other. When they move to a city, they cannot settle in one area and as a result their social network breaks down. This means that as they lose their social network, they also lose their social capital. The persons who have been regarded by the community members as knowledgeable and respectable, when they move to the city are seen as ignorant. The loss of social capital exposes them to poverty and diseases.

Fifth, in the village the farmers owned land - the basic means of productionand produced fruits, vegetables and grains of their choice and reared cattle of their choice. When they move to the city, they lose the right to choose in life. Instead of being producers and decision makers, they turn into voiceless and docile followers. This further takes away their decision-making powers.

Sixth, although Finfinne is located in Oromia, the Ethiopian government discriminatory language policy made Amharic the official language. This language and cultural barrier hinders the Oromo farmer's employability and prevents them from accessing basic services.

Seventh, the Oromo farmers have no marketable city skills. The Ethiopian government did not help them transfer the farm skills to the city. This further creates unhealthy social conditions for the family and community members.

Eighth, the evictions made most of Oromo farmers urban poor. Oromo children faced challenges in attending school and achieving their potential. The children drop out of school and take desperate actions. Young girls go into commercial sex and expose themselves and the community members to HIV/ AIDS. Young boys become street beggars, homeless children and expose themselves to many unhealthy social conditions.

From 1860 to the present, consecutive Ethiopian leaders have attacked the Oromo people collectively. Oromo social, economic, political and cultural institutions have been banned (Dugassa, 2012; Jalata, 2005). Under different regimes, the Oromo people were collectively killed, imprisoned and impoverished. They were enslaved, turned into serfs and used as mine sweepers and as cannon fodder. Consecutive regimes knowingly and unintentionally exposed them to famine and diseases. There are cases where the Ethiopian army deliberately poisoned ponds and foods to kill Oromo people. A good example is the experience of the current chairman of the Oromo Liberation Front (OLF) Dawud Ibsa ${ }^{7}$ If

${ }^{7}$ In early 1980s Dawud Ibsa was a junior OLF cadre. To raise political awareness of the Oromo farmers, Dawud and his team went to villages to talk to farmers. The Ethiopian army instructed farmers to invite the OLF activists to their home and gave them chemically poisoned foods. As a result many died on the spot; Dawud Ibsa survived and was captured. 
the Oromo are attacked collectively they need to do everything possible to collectively protect themselves. They can only guarantee their collective security if they assert their collective rights.

\section{Discussions}

The Oromo people have always made efforts to solve longstanding problems and new ones. As they ask, try to answer, fix and shape, they learn and develop more skills. Developing and strengthening of knowledge and skills is a continuous learning journey that help societies to achieve their full potential. There are different ways of learning. We learn through attending specific courses \& conferences, by action learning, by reflecting on lived experiences; and through sharing of information, insights and ideas. The experiences of the Oromo people under consecutive Abyssinian regimes have clearly taught them that their needs and aspirations have always been discounted and this has made them vulnerable to poverty and diseases and hindered their resiliency. It is most unlikely that the next Abyssinian regime will be any different.

During colonization and after, Oromia has been ravaged by war, human rights violations, easily preventable diseases, and famine. These social problems are primarily the result of human rights violations. Human rights violations include individuals' rights i.e. physical and psychological torture, killing, imprisonment, forced displacement and collective rights i.e. social, economic, political and cultural. The desire of the minority group to rule, exploit the human and natural resources and control the aspirations of the Oromo people has created conflict and instability. Instability in Ethiopia is slowly dripping out all over the world. After the TPLF took power in 1992, the problem further deteriorated. Oromo refugees are now spread all over the world.

The fundamental challenge of public health researchers and policy makers is in trying to answer where do the social ills or diseases begin? Trying to answer these questions, they systematically collect data and define the problems and answer the who, what, where, when and how. These questions help answer how the disease propagated, and what are the risks and protective factors related to the diseases. As they answer these questions, they start to ask the second set of questions; these help them envision strategies about how to reduce risks and widen the protective factors. This leads to the third set of questions-where the researchers and policy makers make efforts to evaluate if the prevention strategies work i.e. healthy policies are implemented and laws and procedures are enforced. By conducting such activities, the Oromo people need to build their institutional capacity; to achieve that, they must assert their collective rights.

Regardless of our social position in society, we have opportunities to learn and teach. On one hand, we grow our knowledge and skills, and steer our personal growth. On the other, we teach others and engage others around us in a positive way and work with them to achieve our societal goals. That is why the principles of collective rights are seen to offer more than a conceptual argument connecting governance and social conditions in which the people work and live. When 
the three major explanations for disease are psycho-social, social production and eco-social, they make clear that our health is socially determined. Indeed, public health extended life expectancy through assessment, policy development and assurances. All of them are political actions.

The Oromo people are an egalitarian society and they identify themselves as "the people of Gada and Odda". When they say they are the people of Gada, they are implying that they are a democratic, equitable, inclusive society and people of law and order. When they say the people of Odda, they are making clear that the Oromo people are accommodators and are environmentally sustainable. Implicitly, they are saying that non-Oromos have nothing to fear from them. They are also telling non-Oromos that they need to be democratic, equitable, inclusive and accommodators. However, as Nelson Mandela once said "Only free men (people) can negotiate, prisoners can't enter into contacts"; many Oromos feel that they are not free to negotiate on unity.

\section{Conclusion}

This paper has raised eight major issues. The first issue is that the European myth about Prester John over-exaggerated the map of Abyssinian territory and provided them with a racist theory. These theories provided theoretical reasons for Abyssinians to colonize the Oromo people and perpetuate collective violence. The myth about Prester John also made the Euro-Abyssinian relationship deeper at an epistemic level. This informed the European empire builders to provide political and military aides to Abyssinia to became and remain a colonial state.

Second, driven by a racist mindset, consecutive Abyssinian regimes step by step colonized Oromia. During colonization, and afterwards, deliberately and unwittingly the regimes compromised the needs and the aspirations of the Oromo people. The social conditions in which the Oromo people lived, and still live, under consecutive Abyssinian regimes made them vulnerable to poverty, disaster and diseases. For example, in 2017, in Oromia and Ogdenia-(Somali speaking region) people are suffering from famine. Instead of providing them relief foods and promoting peace, the Ethiopian government is training and arming the Ogden militia and providing them financial initiatives and attacking the Oromo people.

Third, public health policies and programs are designed with the aim of bettering the health of the population. The purposes of public health are identified as 1) prevention of diseases; 2) protection from environmental hazards; 3) prevention of injury; 4) promotion of healthy behavior; 5) responding to disasters and assisting communities in their recovery; 6) assuring the quality of services (CDC, 2014). Taking all these steps requires political decision-making. Not only that, health is political because the social determinants of health i.e. the social, economic, political, and cultural status are determined by our social status. Hence, if the Oromo people want to improve their public health conditions, they need to reclaim their collective rights and decide on their social, economic, political, cultural and environmental affairs i.e. develop their own social policies, 
stop the widespread evictions, killings, imprisonments and dehumanization.

Fourth, in Oromia, famine, poverty and diseases are the outcome of prolonged physical, social, economic, political, cultural and environmental insecurities. Preventing diseases, reducing poverty and risk factors for disaster and fostering resiliency necessitates building the social, economic, political, cultural and environmental capacity of the Oromo people.

Fifth, the efforts of the Oromo people to assert their collective rights stems from their aspirations to develop contingency plans to define and defend who they are and whom they want to be. They are intended to identify the causes of their social problems, widen their knowledge, develop problem-solving skills and find financially feasible and culturally appropriate solutions to their problems. These efforts are essential for the development of better public health.

Sixth, for over a century consecutive Ethiopian regimes exploited the human and natural resources of the Oromo people, polluted their environment and denied the development of Oromo institutions, thereby limiting their choices in life. The struggle of the Oromo people to self-determination should be seen as the continuous efforts they make to empower themselves, develop their own institutions and widen their choices in life.

Seventh, human rights and public health work synergistically. The Oromo people will benefit if their neighbors are guaranteed human rights, peace and stability. If political organizations are either geared to promote only collective rights or individual rights-as in the case of TPLF's "convenient agenda"-they cannot provide workable solutions. Political groups that are not willing to acknowledge individual and collective rights are prone to violate both sets of rightsbecause "human rights are indivisible and interdependent". Public health needs to promote individual and collective rights. Promoting individual rights and undermining collective rights does not bring sustainable changes.

Eighth, the Ethiopian government's efforts to contain the Oromo uprising through violence are unsustainable. Containing the Oromo uprising and the demands of the Oromo people by violent means is contrary to the principle of human rights. Respect for human rights, human dignity and human security are the central ideas and ideologies that bring peace, unity and stability to Ethiopia. Public health needs to advocate for collective and individuals rights as the instrument of peace, accountability, empowerment, early risk identification and vulnerability reduction.

\section{Declaim}

The paper is solely represents the work of the author.

\section{References}

African Charter on Human and Peoples Rights, Adopted in Nairobi (1981). http://www.achpr.org/instruments/achpr/

Bambra, C., Fox, D., \& Scott-Samuel, A. (2005). Towards a Politics of Health. Health Promotion International, 20, 187-193. https://doi.org/10.1093/heapro/dah608

BBC (2016). Seven Things Banned under Ethiopia's State of Emergency. 
http://www.bbc.com/news/world-africa-37679165

Bulatovich, A. (2000). Ethiopia through Russian Eyes, Country in Transition 1896$1898 m$. Trenton, NJ: The Red Sea Press, Inc.

Bulcha, M. (1994). The Language Policies of Ethiopian Regimes and History of Written Afaan Oromoo: 1844-1994. The Journal of Oromo Studies, 1, 91-115.

Bulcha, M. (1995). Onesimos Nasib's Pioneering Contributions to Oromo Writing. Nordic Journal of African Studies, 4, 36-59.

Bulcha, M. (2002). The Making of the Oromo Diaspora: A Historical Sociology of Forced Migration. Minneapolis, Minnesota: Kirk Hose Publishers.

Bulcha, M. (2005). Genocidal Violence in the Making of Nation and State in Ethiopia. African Sociological Review, 9, 1-54.

CDC (2013). United States Public Health 101. https://www.cdc.gov/stltpublichealth/docs/usph101.pdf

CDC (2014). The 10 Essential Public Health Services. https://www.cdc.gov/nphpsp/documents/essential-phs.pdf

Clay, J., \& Holcomb, B. (1986). Politics and the Ethiopian Famine 1984-1985. New Brunswick and Oxford: Transaction Books.

Da Costa, K., \& Pospieszna, P. (2015). The Relationship between Human Rights and Disaster Risk Reduction Revisited: Bringing the Legal Perspective into the Discussion, Journal of International Humaniterian Legal Studies, 6, 64-66.

Dabaas (1988). I Interviewed Him in Athens, Greece. He Was a Retired Protestant Church Pastor from Eritrea. At That Time He Was about 80 Years Old.

De Salviac, M. (1901/2005). The Oromo: An Ancient People: Great African Nation.

Dugassa, B. (2003). Powerlessness and the HIV/AIDS Epidemics in the Ethiopian Empire. The Journal of Oromo Studies, 11, 31-66.

Dugassa, B. (2004). Human Rights Violations and Famine in Ethiopia. The Journal of Oromo Studies, 11, 47-68.

Dugassa, B. (2005). Women's Rights and Women's Health: The Case of Oromo Women in Ethiopia. Journal Health Care for Women International, 26, 149-169. https://doi.org/10.1080/07399330590905594

Dugassa, B. (2006a). Ethiopian Language Policy and Health Promotion. Journal of Sociology and Social Welfare, XXXIII, 69-86.

Dugassa, B. (2006b). Knowledge, Identity and Power: The case of Ethiopia and Ethiopianess. The Journal of Oromo Studies, 13, 57-81.

Dugassa, B. (2008). Colonial Trauma, Community Resiliency and Community Health Development: The Case of the Oromo people in Ethiopia. Journal of Health \& Development, 4, 43-63.

Dugassa, B. (2009). Women's Rights and Women's Health, during HIV/AIDS Epidemic. Journal Health Care for Women International, 30, 1-17.

Dugassa, B. (2012). Denial of Leadership Development and the Underdevelopment of Public Health: The Experience of the Oromo People in Ethiopia. Journal of Oromo Studies, 19, 139-174.

Dugassa, B. (2013). Iodine Deficiency and Women's Health: Colonialism's Malign Effect on Health in Oromia Region, in Ethiopia. Health, 5, 958-972. https://doi.org/10.4236/health.2013.55127

Dugassa, B. (2014a). Human Rights and Public Health: Toward Understanding the Root Causes of Social Problems in the Oromia Regional State, in Ethiopia. Saarbrücken: Lambert Academic Publishing. 
Dugassa, B. (2014b). In Defense of the Latest Amnesty International (AI) Report on Repression in Oromia,

http://finfinnetribune.com/Gadaa/2014/11/begna-dugassa-phd-in-defense-of-the-latest -amnesty-international-report-on-the-repression-in-oromia/

Foucault, M. (1980). Power/Knowledge. Brighten: Harvester.

Harley, J. (1989). Deconstructing the Map. Cartographica, 26, 1-20. https://doi.org/10.3138/E635-7827-1757-9T53

Hirst, D. (1999). Human Waves Fall as War Aims Unfold. https://www.theguardian.com/world/1999/may/18/ethiopia

Holcomb, B., \& Ibssa, S. (1990). The Invention of Ethiopia: The Making of a Dependent Colonial State in North Africa. Trenton, NJ: The Red Sea Press, Inc.

ICESCR (1966). International Covenant on Economic, Social and Cultural Rights. http://www.ohchr.org/EN/ProfessionalInterest/Pages/CESCR.aspx

ICCPR (1966). International Covenant on Civil and Political Rights. http://www.ohchr.org/en/professionalinterest/pages/ccpr.aspx

Jalata, A. (2005). Oromia and Ethiopia. State Formation and Ethnonational Conflict 1868-2004. Trenton, NJ: The Red Sea Press, Inc.

Lata, L. (2000). The Ethiopian State at the Crossroads: Decolonization, Democratization or Disintegration? Trenton, NJ: The Red Sea Press, Inc.

Legesse, E. (2014). YeMeles Tirufatoch, Balebet Alba Ketema. Washington DC: Netsanet Publishing Agency.

McCaskill, D., FitzMaurice, K., \& Cidro, J. (2011). Toronto Aboriginal Research Project. Toronto: Toronto Aboriginal Support Services Council.

Mekuria, T. T. (1982/1989). Atse Yohanis ina YeItyophia Andinet, Kuraz Asatami Dirjiti.

Mekuria, T. T. (1985/1992). Atse Minilik ina YeItyophia Andinet, Kuraz Asatami Dirjiti.

Midega, M. (2014). The Politics of Language and Representative Bureaucracy in Ethiopia: the Case of Federal Government. Journal of Public Administration and Policy Research, 7, 15-23.

Pankhurst, R. (2005). Institute of Ethiopian Studies, Addis Ababa, Innovation and Misoneism during the Reign of Emperor Yohannes IV (1872.1889). Aethiopica, 8, 48-71.

Pankhurst, A. (1992). Resettlement and Famine in Ethiopia: The Villagers Experience. Manchester: University Press.

Ramos, M. (2003). The Myth of Prester John and Iberian Visions of Ethiopia. Proceedings of the International Seminar on Pedro Páez in 17th Century Ethiopia, Addis Ababa, 9-11 December 2003.

Reta, A., \& Adisu, S. (2005/2012). Yeraya Hizbi Yemaninet Tiyaqe ina Yemaikelawi Mengistat Milash Keathe Yohanis 4nya Iske EHADEG.

Richter, E. (2008). Commentary Genocide: Can We Predict, Prevent, and Protect? Journal of Public Health Policy, 29, 265-274.

Yilma, A. S. (2006/2013). Abeto Iyasu Anesasina Awedadeqi, Addis Ababa.

UDHR (1948). The Universal Declaration of Human Rights. http://www.un.org/en/universal-declaration-human-rights/

UN Vienna Declaration (1993). Vienna Declaration and Programme of Action. http://www.ohchr.org/EN/ProfessionalInterest/Pages/Vienna.aspx

WHO (1998). Health Promotion Glossary. Geneva: World Health Organization, Division of Health Education and Communication, WHO/HRR/HEP/98.1.

WHO (2002). 25 Questions \& Answers on Health \& Human Rights. Health \& Human 
Rights Publication Series Issue No. 1. Geneva: WHO.

WHO (2002). Collective Violence. In WHO, World Report on Violence and Health, Geneva, 213-237. http://apps.who.int/iris/bitstream/10665/42495/1/9241545615_eng.pdf

WHO (2006). Constitution of the World Health Organization.

http://www.who.int/governance/eb/who_constitution_en.pdf

Submit or recommend next manuscript to SCIRP and we will provide best service for you:

Accepting pre-submission inquiries through Email, Facebook, LinkedIn, Twitter, etc. A wide selection of journals (inclusive of 9 subjects, more than 200 journals) Providing 24-hour high-quality service User-friendly online submission system Fair and swift peer-review system Efficient typesetting and proofreading procedure Display of the result of downloads and visits, as well as the number of cited articles Maximum dissemination of your research work

Submit your manuscript at: http://papersubmission.scirp.org/

Or contact sm@scirp.org 